\title{
The Relationship Between Economic Value Added and Earnings Per Share: An Empirical Analysis of the Turkish Cement Industry
}

\author{
Murat Azaltun, Irem Batibay, Ilker Calayoglu \\ Okan University, Istanbul, Turkey
}

EVA is an acronym for economic value added, is a measure of corporate performance that differs from most others by including a charge against profit for the cost of all the capital a company employs. EVA is much more than just a measure of performance. It is the framework for a complete financial management and incentive compensation system that can guide every decision a company makes. It combines factors, such as economy, accounting, and market information in its assessment. The main objective of this study is to introduce the concept of Economic Value Added (EVA) and compare with the method of Earnings Per Share (EPS). This study aims to determine the effect of the Economic Value Added and Fundamental Analysis of the company's earnings per share in the cement industry sector. Especially, the study is examined the economic crisis period 2000-2001 and 2007-2008 and their reflection to the financial statements of the cement companies. The methodology used in this research is a web-based data collection is the company's financial statements and the company's earnings per share amount which is then processed and analyzed using Microsoft Excel. Having obtained the results of analysis using Microsoft Excel, then the data are performed using the SPSS 17 statistical test to determine the effect of the Economic Value Added and Fundamental Analysis of the company's earnings per share. This study employs pooled time-series, cross sectional data of listed 15 cement companies in the Istanbul Stock Exchange (IMKB) over the period 1999-2010 to examine whether EVA or Earnings Per Share (EPS) is associated more strongly with companies performance. Findings indicated that the proponents of EVA provided evidence to establish this method as a superior performance measurement and incentive compensation system and claimed that it is really better to use EVA, than Earnings per Share Method.

Keywords: performance measures, EPS, EVA, Turkish cement industry, Economic Value Added (EVA), Earnings Per Share (EPS)

Murat Azaltun, Assistant Professor, Department of Accounting and Financial Management, School of Applied Sciences, Okan University.

Irem Batibay, Ph.D. candidate, Department of Accounting and Financial Management, School of Applied Sciences, Okan University.

Ilker Calayoglu, Ph.D. candidate, Department of Accounting and Financial Management, School of Applied Sciences, Okan University.

Correspondence concerning this article should be addressed to Irem Batibay, Okan University, School of Applied Sciences, Department of Accounting and Financial Management, Campus Box 34959, Tuzla, Istanbul, Turkey. E-mail: irem.batibay@okan.edu.tr. 


\section{Introduction}

Maximizing shareholders value has become the new corporate paradigm in recent years. Shareholder's wealth is measured in terms of returns they receive on their investment. It can either be in forms of dividends or in the form of capital appreciation or both. Capital appreciation depends on the changes in the market value of the stocks.

The market value of stocks depends upon number of factors ranging from company specific to market specific. Financial information is used by various stakeholders to assess firm's current performance and to forecast the future as well.

EVA has following principles:

(1) EVA helps in reducing agency conflict and improve decision making (Lovata \& Costigan, 2002);

(2) EVA is more strongly associated with stock return than other measures (Maditinos \& Sevic, 2006);

(3) EVA improves stock performance (Ferguson, Rentzler, \& Yu, 2005);

(4) EVA adds more informational content in explaining stock returns (Erasmus, 2008).

As Drucker puts in his 1995 Harvard Business Review article:

EVA is based on something it has been known for a long time: What it has been called profits, the money left to service equity, is usually not profit at all. Until a business returns a profit that is greater than its cost of capital, it operates at a loss. Never mind that it pays taxes as if it had a genuine profit. The enterprise still returns less to the economy than it devours in resources... Until then it does not create wealth; it destroys it. (Drucker, 1995, p. 54)

Many corporate managers have forgotten this basic principle because they have been conditioned to focus on conventional accounting profits, which include a deduction for interest payments on debt but have no provision at all for the cost of equity capital, worse still, most line managers focus on operating profits, which do not even have a charge for debt. True profits do not begin until the cost of capital, like all other costs, has been covered.

EVA is a measure of those true profits. Arithmetically, it is after-tax operating profits minus the appropriate capital charge for both debt and equity. What remains are the amount by which profits in any given period exceed of fall short of the cost of all capital used to produce those profits. This is a number that economist refers to as residual income, which means exactly what it implies: it is the residue left over after all costs have been covered. Economists also refer to this as economic profit or economic rent. Accountant calls it EVA, for economic value added. It is simple, though the actual calculation of EVA is somewhat more complicated. It first requires a number of decisions about how to properly measure operating profits, how to measure capital, and how to determine the cost of capital (Ehrbar, 1998).

\section{The Concept of EVA}

A concept critical in evaluating the performance of any business is economic value added. In generic terms, value added refers to the additional or incremental value created by an activity or a business venture. Economic value added is a refinement of this concept-it measures the economic rather than accounting profit created by a business after the cost of all resources including both debt and equity capital have been taken into account. Economic value added is a financial measure of what economists sometimes refer to as economic profit or economic rent. The difference between economic profit and accounting profit is essentially the cost of equity capital —an accountant does not subtract a cost of equity capital in the computation of profit, so in fact 
an accountants measure of income or profit is in essence the residual return to that equity capital since all other costs have been deducted from the revenue stream. In contrast, an economist charges for all resources in his computation of profit-including an opportunity cost for the equity capital invested in the business - so an economist's definition and computation of the profit is net above the cost of all resources (Boehlje, 2000).

\section{The Relationship Between Positive and Negative EVA With Accounting Performance}

Companies with positive EVA's will lead to better organisation and have strong market positions. This study believes that companies that have positive EVA value or value creator companies have a strong accounting returns and better market positions. In addition, they might also have higher profits and good accounting indicators, since a positive EVA is indicative that companies have high excess profit after deducting cost of investments. This again will be indicating that, the company is well organised in reaping higher returns exceeding investor's expectations. Returns on investment made by this type of company will also be higher than returns expected by the investors.

\section{The Relationship Between Positive and Negative EVA With Stock Return}

Positive EVA means the company is experiencing an excess of net operating profit after tax (NOPAT) after deducting the charge for capital (both debt and equity) which is obtained by multiplying the percentage of weighted average cost of capital (WACC). It means the company had excess real profit that the company gained after deducting cost of investment by investors from net profit.

It is the norm nowadays for companies to only declare profit that, while not taking into account of the cost of capital or investment. In contrast, for value destroyer companies (negative EVA) the net profit is not enough to cover the cost of investment by investors. The negative EVA means that a company is running in losses, after deducting the cost of capital.

Turvey studied the relationship of the highs and lows of EVA against market return (Tuvey, Van Duren, \& Sparling, 2000). Their results were consistent with other researchers that, positive EVA will correlate with higher market return.

\section{Literature Review}

There are some studies that do and some that do not support the claim that EVA provides better stock returns. Biddle analyzed a sample of firms over the period 1984-1993 by comparing the stock market adjusted returns against EVA, Residual Income, and Operating Cash Flow (Biddle, Bowen, \& Wallace, 1997). The results do not support that EVA dominates traditional performance measures in its association with the stock market returns. Ismail conducted a study on EVA and its association with stock returns viz-a-viz accounting earnings and stock returns and found that net operating profit after taxes and net income outperform EVA in explaining stock returns. Further, this study states that accruals and operating cash flows have significant incremental information content than EVA (Ismail, 2006).

P. P. Peterson and D. R. Peterson (1996) analyzed traditional and value-added measures of performance and their relationship with stock returns. Their findings state that traditional measures are not empirically less related to stock returns than return on value added measures. Kyriazis and Anastassis in their study of Greek firms concluded that relative information content tests reveal that net and operating income appear to be more valuable than EVA (Anastassis \& Kyriazis, 2007). EVA components add only marginal information content as 
compared with accounting profit (Sharma, 2010).

Proponents of EVA claim that EVA is highly correlated with stock returns. Lefkowitz analyzed the US companies and a result of the study supported Stern-Stewart hypothesis, i.e., EVA is better correlated with stock returns as compared with traditional performance measures (Lefkowitz, 1999). They found that EVA is a reasonably reliable guide to understand the firm's value. Lehn and Makhija investigated the degree of correlation between different performance measures and stock market returns (Lehn \& Makhija, 1997). The results indicate that EVA is the highest correlated measure with stock returns.

\section{Research Data and Methodology}

EVA is defined as the amount of net operating profit after tax (NOPAT) minus the charge for capital (both debt and equity) obtained by multiplying the percentage of weighted average cost of capital (WACC). EVA is an estimate of the amount by which earnings exceed or fall short of the rate of return shareholders and lenders could get by investing in other securities of comparable risk and includes a charge against profit for the cost of all the capital a company employs.

EVA calculation steps:

(1) Calculate Net Operating Profit After Tax (NOPAT);

(2) Identify company's Capital (C);

(3) Determine a reasonable Capital Cost Rate (CCR);

(4) Calculate company's Economic Value Added (EVA).

EVA $=$ Net operating profit after taxes - Cost of capital

Calculating Net Operating Profit After Taxes (NOPAT), NOPAT is easy to calculate. From the income statement we take the operating income and subtract taxes.

$$
\text { NOPAT }=\text { Operating Income }- \text { Taxes }
$$

Calculating Cost of Capital:

$$
\text { Cost of Capital }=\text { TC } \times \text { WACC }
$$

where, $\mathrm{TC}=$ Total Capital, and WACC $=$ Weighted Average Cost of Capital.

$$
\text { EVA }=\text { NOPAT }- \text { WACC } \times \text { TC }
$$

Exploratory designs and correlational method have been chosen for this study, since the purpose of the study is to explore the relationship of EVA as company performance method and Earnings per Share Method. The analysis will use time series and cross section analysis simultaneously. The findings on each performance tool and earnings per share is analysed at this level.

The sample of the companies comprises the public listed cement companies in Istanbul Stock Exchange over the period 1999 to 2010. Based on these criteria, for period 1999 to 2010, 15 companies are involved.

Cement industry is chosen for this research, because cement industry is a basic industry which plays an important role in the process of economic development of the country. It is an essential material for building infrastructure like dams, bridges, hospitals, and plants. Consequently, the cement industry has a manifold accelerating effect on activities in many sectors of the economy. Thus the extent of forward and backward linkages of cement industry highlights its prominence in fitter industry growth. This industry is also significant from the point of view of direct and indirect employment it generates, revenue contribution by way of taxes and duties to government and catering to basic standard of living, namely, housing.

Cement industry has been accorded a significant place in the scheme of priorities for facilitating 
investment process in the industrial development. It is produced both in public and private sectors. Certain guidelines were adopted for the private sector in order to augment production without encouraging the concentration of economic power.

In this research 15 cement companies, which exist in IMKB are used. These companies are shown in Table 1.

Table 1

Name of the Listed Cement Industry Companies in Istanbul Stock Exchange

Name of the companies

ADANA ÇiMENTO SANAYIII T.A.Ş.

AFYON ÇIMENTO SSANAYIII T.A.S.

AKÇANSA ÇIMENTO SANAYI VE TICARET A.Ş.

ASLAN ÇIMENTO A.S..

BATICIIM BATI ANADOLU ÇIMENTO SANAYIII A.S.

BATISÖKE SÖKE ÇIMENTO SANAYİ T.A.Ş.

BOLU ÇIMENTO SANAYIII A.Ş.

BURSA ÇIMENTO FABRIKKASI A.Ş.

CIMENTAS İZMİR CIMMENTO FABRİKASI T.A.S.

ÇIMSSA ÇIMENTO SANAYİ VE TİCARET A.Ș.

GÖLTAŞ GÖLLER BÖLGESİ ÇİMENTO SAN. VE TİC.A.Ş.

KONYA ÇIMENTO SANAYIII A.S.

MARDIN ÇIMENTO SANAYİi VE TICARET A.Ş.

NUH ÇIMENTO SANAYIII A.Ş.

ÜNYE ÇİMENTO SANAYİ VE TİCARET A.Ş.

The balance sheet and income statement of all companies are achieved from IMKB (Istanbul Stock Exchange Market) and KAP (Kamuyu Aydınlatma Platformu—Public Disclosure Platform).

Table 2 shows the calculations of CCR, NOPAT, and EVA of the Adana Cement Company. The calculations are made with the company's balance sheet and income statement reports for the years between 1999 and 2010. Some assumptions are made for calculating EVA. Government bond interest rates have been assumed as an alternative cost of capital. The bold figures in Table 2 show that Adana Cement Company had negative EVA on the years 1999, 2000, and 2001. It means that on those years the company was losing value on its capital-consuming activities

Table 2

CCR, NOPAT, and EVA of the Adana Cement Company

\begin{tabular}{|c|c|c|c|c|c|c|c|c|c|c|c|c|}
\hline & 1999 & 2000 & 2001 & 2002 & 2003 & 2004 & 2005 & 2006 & 2007 & 2008 & 2009 & 2010 \\
\hline CCR & 0.075002 & 0.0911985 & 0.1597802 & 0.1612683 & 0.1617494 & 0.156620 & 0.0098072 & 0.0120197 & 0.0232866 & 0.029810 & 0.0309954 & 0.0265390 \\
\hline NOPAT & $32,605,213$ & $49,617,679$ & $49,678,092$ & $126,253,944$ & $133,234,965$ & $83,705,239$ & $36,609,726$ & $42,504,742$ & $14,232,860$ & $9,484,165$ & $10,993,540$ & $14,689,471$ \\
\hline EVA & $-20,986,302$ & $-6,775,683$ & $-35,471,290$ & $20,297,141$ & $41,190,617$ & $3,159,343$ & $33,135,417$ & $38,944,305$ & $10,271,684$ & $5,014,603$ & $8,076,458$ & $12,014,119$ \\
\hline
\end{tabular}

Table 3 shows the calculated EVA of the companies. As it is seen most of the variables are negative, which means that the companies have lost value by investing in capital-consuming activities (Çakıc1, 2008). As it is seen after the economic crisis in 2000-2001 and 2007-2008, most of the companies begin to have more negative EVA.

Table 4 shows the Earnings per Share of the companies during the years. As it is seen during and after the economic crisis in 2000-2001 and 2007-2008, most of the companies begin to have less EPS. The bold figures in Table 4 show EPS values below zero mean that the company is losing money. 
Table 3

Calculated EVA of the Cement Industry Listed Companies

\begin{tabular}{|c|c|c|c|c|c|c|c|c|c|c|c|c|}
\hline ompanies & 1999 & 2000 & 2001 & 2002 & 2003 & 2004 & 2005 & 2006 & 2007 & 2008 & 2009 & 2010 \\
\hline Adana Çimento & $12,014,119.99$ & $8,076,458.11$ & $5,014,603.72$ & $10,271,684.98$ & $38,944,305.84$ & $33,135,417.67$ & $3,159,343.02$ & $41,190,617.92$ & $20,297,141.24$ & $-35,471,290.02$ & $-6,775,683.91$ & $-20,986,302.11$ \\
\hline Afyon Çimento & $-132,434.81$ & $-553,475.08$ & $-1,040,411.95$ & $836,908.68$ & $-9,527,068.45$ & $-3,041,068.93$ & 4,469,599.04 & $5,175,516.07$ & $-19,999,099.41$ & $-9,263,093.16$ & $-7,591,776.33$ & $-5,504,159.95$ \\
\hline Akçansa Çimento & $-25,404,987.81$ & $-46,440,594.71$ & $-49,311,846.76$ & $-72,588,653.51$ & $-235,614,823.51$ & $-166,162,017.29$ & $-7,558,773.01$ & $15,422,229.74$ & $-12,925,292.77$ & $4,645,597.52$ & $-16,005,388.75$ & $-27,000,346.65$ \\
\hline Aslan Çimento & $-3,743,366.13$ & $-10,882,896.99$ & $-15,037,145.36$ & $-10,995,836.45$ & $-73,955,857.64$ & $-47,438,772.97$ & $-2,046,317.18$ & $9,970,550.52$ & 6,295 & 12.47 & $-52,854,423.46$ & $-18,5$ \\
\hline Batısöke Çimento & $-10,923,532.58$ & $-19,600,481.69$ & $-23,786,346.02$ & $-25,199,981.04$ & $-71,477,407.28$ & $-51,736,066.05$ & $-8,521,947.99$ & 2,074,997.71 & $-15,810,654.16$ & $-28,622,690.30$ & $-16,396,302.81$ & $-15,433,868.33$ \\
\hline Bolu Çimento & $-6,570,871.95$ & $-16,485,650.05$ & $-17,595,131.91$ & $-21,735,828.26$ & $-45,381,886.26$ & $-33,162,350.81$ & $9,435,399.97$ & $35,310,615.49$ & $-776,774.39$ & $-1,540,657.90$ & $-10,793,675.17$ & $-6,230,386.21$ \\
\hline Bursa Çimento & $-3,839,301.94$ & $-8,409,244.45$ & $-8,636,990.27$ & $-11,092,639.51$ & $-58,155,861.61$ & $-27,056,099.46$ & $15,560,321.70$ & $31,415,713.90$ & $11,057,776.95$ & $-16,613,815.00$ & $-33,519,657.42$ & $-26,530,217.76$ \\
\hline Çimentaş Cimento & $-12,630,956.86$ & $-16,589,627.91$ & $-24,613,747.88$ & $-17,010,397.75$ & $-94,738.08$ & $-69,081.39$ & $-48,235.78$ & $-64,356.96$ & $-71,424.18$ & $-98,400.77$ & $-22,274.40$ & $-57,755.84$ \\
\hline Göltaş Çimento & $1,751,447.67$ & $-876,212.80$ & $-13,552,112.99$ & $-8,671,307.26$ & $-79,376,087.77$ & $-32,663,029.27$ & $-3,792,604.23$ & $-14,529,543.85$ & $-60,856,077.83$ & $-45,709,640.51$ & $-27,703,772.15$ & $-32,323,950.97$ \\
\hline Konya Çimento & $-1,282,526.16$ & $-5,313,893.16$ & $-13,293,536.43$ & $-11,580,856.86$ & $-73,513,715.98$ & $-49,028,977.02$ & $971,235.82$ & $15,530,137.31$ & $-10,124,827.65$ & $-40,332,424.87$ & $-24,646,070.95$ & $-7,994,688.13$ \\
\hline Mardin Çimento & $-1,024,743.70$ & $-3,671,710.54$ & $-3,454,068.98$ & $-7,145,144.51$ & $-27,231,613.02$ & $-12,349,926.40$ & $34,048,599.28$ & $51,556,068.45$ & $37,078,230.81$ & $20,114,547.00$ & $46,396,508.14$ & $43,984,703.55$ \\
\hline Nuh Çimento & $-8,632,356.64$ & $-25,553,963.37$ & $-29,304,181.51$ & $-31,409,261.58$ & $-231,405,496.62$ & $-101,804,521.62$ & $21,013,259.73$ & $26,955,106.71$ & $46,945,214.88$ & $-3,783,069.63$ & $-21,438,917.63$ & $-50,882,376.25$ \\
\hline Ünye Çimento & $-5,033,955.12$ & $-13,426,534.72$ & $-11,926,055.86$ & $-74,142,673.27$ & $-76,296,233.88$ & $-53,658,157.98$ & $31,107,307.71$ & $34,076,050.48$ & $16,941,743.66$ & $5,164,044.59$ & $8,840,884.58$ & $12,885,890.79$ \\
\hline
\end{tabular}

Table 4

Earnings Per Share of the Cement Industry Listed Companies

\begin{tabular}{|c|c|c|c|c|c|c|c|c|c|c|c|c|c|}
\hline & 1999 & 2000 & 2001 & 2002 & 2003 & 2004 & 2005 & 2006 & 2007 & 2008 & 2009 & 2010 & Average EPS of Company \\
\hline Adana Çimento & 1.30 & 0.65 & 1.21 & 0.58 & 0.33 & 0.48 & 1.02 & 1.44 & 1.47 & 0.66 & 0.48 & 0.63 & 0.853 \\
\hline Afyon Çimento & 0.05 & 0.04 & -0.04 & 0.21 & 0.12 & 0.97 & 0.86 & 1.06 & 0.96 & 0.30 & -0.00 & 0.00 & 0.377 \\
\hline Akçansa Çimento & 0.29 & 0.07 & 0.16 & 0.18 & 0.02 & 0.04 & 0.59 & 0.77 & 0.97 & 0.54 & 0.39 & 0.31 & 0.362 \\
\hline Aslan Çimento & 0.11 & -0.52 & -1.20 & 0.35 & 1.22 & 0.72 & 2.87 & 6.21 & 5.59 & 1.64 & -4.86 & 0.46 & 1.050 \\
\hline Batıçim Çimento & 0.41 & 0.14 & 0.59 & 0.27 & 0.15 & 0.20 & 0.59 & 1.22 & 0.78 & 0.26 & 0.14 & 0.21 & 0.413 \\
\hline Batısöke Çimento & 0.27 & 0.14 & 0.37 & 0.51 & 0.40 & 0.10 & 0.36 & 0.62 & 0.01 & 0.34 & 0.02 & 0.06 & 0.267 \\
\hline Bolu Çimento & 0.27 & 0.15 & 0.51 & 0.46 & 0.25 & 0.22 & 0.30 & 0.55 & 0.38 & 0.31 & 0.12 & 0.10 & 0.301 \\
\hline Bursa Çimento & 0.35 & 0.25 & 0.96 & 0.55 & 0.40 & 0.62 & 1.07 & 0.81 & 0.69 & 0.43 & 0.05 & 0.11 & 0.522 \\
\hline Çimsa Çimento & 0.64 & 0.80 & 1.66 & 0.56 & 0.05 & 0.05 & 0.09 & 0.11 & 0.02 & 0.01 & 0.01 & 0.01 & 0.333 \\
\hline Göltaş Çimento & 1.12 & 0.91 & 0.44 & 1.85 & 1.34 & 2.19 & 0.03 & 0.03 & -3.16 & 8.41 & 0.67 & 0.65 & 1.206 \\
\hline Konya Çimento & 1.29 & 0.52 & 0.11 & 2.34 & 3.46 & 4.49 & 9.38 & 12.84 & 9.71 & 7.34 & 4.69 & 7.37 & 5.294 \\
\hline Mardin Çimento & 1.53 & 1.55 & 2.05 & 1.04 & 0.71 & 0.53 & 0.81 & 0.98 & 1.04 & 0.76 & 0.81 & 0.71 & 1.043 \\
\hline Nuh Çimento & 0.69 & 0.44 & 0.74 & 0.35 & 0.29 & 0.43 & 0.81 & 0.98 & 1.54 & 1.00 & 0.64 & 0.35 & 0.689 \\
\hline Ünye Çimento & 0.53 & 0.44 & 0.33 & -0.84 & -0.54 & 0.17 & 0.71 & 0.84 & 0.92 & 0.70 & 0.52 & 0.37 & 0.346 \\
\hline
\end{tabular}




\section{Results}

Proponents of EVA provided evidence to establish this method as a superior performance measurement and incentive compensation system and claimed that it is really better to use EVA than traditional accounting performance measures such as Earnings Per Share (EPS).

EVA's during years have a positive correlation between each other. EPS of companies are also positively correlated according to years. But when analyzing the correlation between EVA and EPS, it is obvious that there is not appropriate relationship.

The results of this study show that earnings per share method are not a confidential method for calculating company's performance. The reason is that the manipulative and speculative information can affect the stock prices. And according to this influence companies earning per share can have different amounts than it should be. EPS ratios change too quickly and too much to be of any real use for financial analysis.

The collected data of this study are examined from the balance sheets and income statements of the companies in the sector one by one. It has been explained before how the EVA calculation should be. But it is necessary to recall that the starting point for the calculation is the companies' operating profit and loss accounts. The research has showed that most companies have profit on their financial statements while they have a negative EVA. This means that most of the companies in this industry make profit from operations other than their main activities. This can be another research topic to study.

\section{References}

Anastassis, C., \& Kyriazis, D. (2007). The validity of the economic value added approach: An empirical application. European Financial Management, 13(1). 71-100.

Biddle, G. C., Bowen, M. R., \& Wallace, J. S. (1997). Does EVA beat earnings?-Evidence on associations with stock returns and firm values. Journal of Accounting and Economics, 24(3), 301-336.

Boehlje, M. (2000). Economic value added, strategic business planning for commercial producers, center for food and Agricultural Business, Purdue University. $\quad$ Retrieved from http://www.agecon.purdue.edu/extension/sbpcp/resources/creatingvalue.pdf

Çakıcı, C. (2008). Ekonomik Katma Değer Yaklaşımı (p. 16). İstanbul: Beta Yayınları.

Drucker, P. (1995). The information executives truly need. Harvard Business Review, 73(1), 54-63.

Ehrbar, A. (1998). EVA the real key to creating wealth. New York: John Wiley \& Son's.

Erasmus, P. D. (2008). The relative and incremental information content of the value based financial performance measure cash value added (CVA). Management Dynamics, 17(1), 2-15.

Ferguson, R., Rentzler, J., \& Yu, S. (2005). Does economic value added (EVA) improve stock performance or profitability? Journal of Applied Finance, 15(2), 101-113.

Ismail, A. (2006). Is EVA associated with stock return than accounting earnings? The UK evidence. International Journal of Managerial Finance, 2(4), 343-353.

Lefkowitz, S. D. (1999). The correlation between EVA and MVA of companies (MBA dissertation, California State University).

Lehn, K., \& Makhija, A. K. (1997). EVA, accounting profits, and CEO turnover: An empirical examination. Journal of Applied Corporate Finance, 10(2), 90-96.

Lovata, L. M., \& Costigan, M. L. (2002). Empirical analysis of adopters of economic value added. Management Accounting Research, 13, 215-228.

Maditinos, I. D., Sevic, Z., \& Theriou, N. (2006). The introduction of economic value added (EVA) in the corporate world. Proceedings from The International Conference: Innovation, Entrepreneurship and Competitiveness in Balkan and Black Sea Countries. Kavala, Greece.

Peterson, P. P., \& Peterson, D. R. (1996). Company performance and measures of value added. Charlottesville, V.A.: The Research Foundation of the Institute of Chartered Financial Analysts.

Sharma, K. A. (2010). Economic value added (EVA)—Literature review and relevant issues. International Journal of Economics and Finance, 2(2), 200-220.

Tuvey, C. L., Van Duren, E., \& Sparling, D. (2000). The relationship between economic value added and the stock market performance of agribusiness firms. Agribusiness, 16(4), 399-416. 